\title{
The Glasgow University Library-Its Growth
}

\section{by Donations.}

An Address by Ex-Propessor Dickson, D.P., LL.D., at th. wecting of Stirlings' Library, Glasgow, $13^{\text {th }}$ Aprit, 1896, and reprinted from the Report of the Proceedings.

WAS asked by my friend, Dr. Mitchell, to come here to-day and give an "Address." That delightfully vague word opens up various possibilities of loquacity on the one side and of longsuffering on the other, but it affords little practical help towards a solution of the problem which it sets-towards its own definite embodiment in a form suited to the place and time.

Dr. Mitchell has come to the help of my perplexity by suggesting a slight notice of the fortunes of the University Library. He believes that not much is known regarding it by those unconnected with the University; for at the time when Mr. Mason was preparing his interesting account of Glasgow Libraries, it was undergoing a process of transfer and rearrangement, which left its staff no leisure at the moment to narrate its history, and the Notes which I subsequently drew up for the information of the Library Association on its visit to Glasgow in 1888 did not pass into general circulation. He believes that there may be a certain knowledge on my part of the titles, if not of the contents, of the books, for I have passed most of them under review; how far its outcome may have equal interest for others remains to be seen. Much may depend on the point of view from which it is approached. This is hardly the place to speak of its distinctive aims and functions as bearing on the studies of the University-on its provisions, resources, defects, needs, possibilities, as an academic instrument. I have harped on this string before, and may have occasion to recur to it. Here and now I shall speak of it simply as one of our great Libraries_still, for the time being, the largest in Glasgow (whatever may be Mr. Barrett's expectations in a 
not very remote future), maintained chiefly from national resources for national ends, and-while destined in the main for academic use-open and available for consultation to all comers. I shall look at it, not from the theoretical standpoint of what it ought to be, but from the practical standpoint of what it is, and of how it has come to be what it is. Such a Library is not wholly a result either of mere accident or yet of formal design, but a historical growth, which yields variety of character and interest; and, if it brings not a little disillusion to the fancy of the rustic who, learning that it long had the privilege of getting all English books if it claimed them, expects it to possess them all, provides some surprises and compensations in the happening of the unexpected.

I shall not now enter into the earlier history of the collection, although it presents various features of interest. Though the University was founded in 1451 , and soon after received a few MSS., of which no trace remains, the Library, as it now exists, dates from 1577 , the epoch of the new charter of James VI., of the energy of Andrew Melville, and the public spirit of George Buchanan. Its progress was slow and desultory, the result of various haphazard but welcome gifts, combined with occasional acquisitions by purchase from the Quaestor's box, however replenished. The first glimpse of books bought in 1577 is of good omen for the representative character of the nascent institution, for it supplied Augustine's works for the theologian, Cicero for the humanist, Aristotle for the philosopher, while it ministered to the guidance of daily life by "the hail Actes of Parliament" on the one hand and the "Bible of Govan and the College" on the other. Nearly a hundred years later the Visitors reported the Library "but verie small for ane Universitie, and having no considerable ways to better the samen by the Universitie's awen care." It is doubtful whether by 1700 the number of volumes exceeded 4,000. About 1790 it is estimated at 20,000 , and in 1836 , when the Copyright privilege ceased, it had probably reached 40,000 . The number of volumes in the General Library of the University at the present time may be taken roundly at $160, \infty 00$. This does not include the Hunterian Library, administered in connection with the Museum, which has about 13,000 volumes, or the Library attached to the Divinity Hall, which has about 7,500.

The General Library has been built up mainly from three sources-(1) Privilege under the Copyright Act ; (2) Purchase 
trom a Parliamentary grant given as compensation for its surrender ; and (3) Donations, whether gifts of individual books or bequests of special collections.

I. From the passing of the Copyright Act of 1709 up to 1836 the Library was, along with ten others, legally entitled to be furnished, on demand, with a copy of every book entered in Stationers' Hall. But the privilege was far from yielding all that might be expected of it, or from bearing those only too copious and not a little burdensome fruits which it has yielded of late years to the summons of the Advocates' Library. It appeared in theory greatly more valuable than it proved in practice. Authors and booksellers complained, not without reason, that it imposed a grievous burden, especially when production was costly and the impression limited; and the beneficiaries found difficulty in exacting their right or turning it to account. It needed an agent in London to make the demand and to collect and forward the books, and this was not regularly provided until sixty years after the Act passed, when (in 1774) John Murray, bookseller in London, was appointed as factor, and was "to receive one guinea annually for his trouble." Doubtless he took more trouble than he was paid for, from "the honour of the thing"; but even though he was paid, in I781, $£ 6$ I5s. on account of books so sent, the claim was doubtless but partially and irregularly enforced, and the accruing spoil was, in many cases, barely thankworthy. The response was but grudgingly given, often fitfully and imperfectly, as respects works issued in series or parts, or illustrated by plates. The books were often supplied merely in sheets, and the expense of binding what was hardly worthy of it was found a considerable drawback to the privilege. While the Library got freely quantities of what Professor M'Gill called " idle books," novels of the Minerva Press, fugitive verses, school-books, juvenile literature, occasional sermons, and ephemeral pamphlets, it missed much that was valuable, or had to be content with an imperfect supply. When the privilege was commuted, Glasgow was found to have made most use of it ; $£ 800$ was claimed, and $£ 707$ given, as annual compensation for its surrender; St. Andrew's got $\ell_{630}$; Edinburgh, $£ 575$; and Aberdeen, $£ 320$.

II. For the last sixty years' a sum of about $£ 760$ has been available annually for the purchase of selected books, being the $£ 707$ of Parliamentary grant, and about $£ 50$ as the interest of some small legacies. During this period the Library has gained 
two-thirds of its contents; and the change has greatly extended its usefulness and value, not merely by excluding such worthless elements as accrued under the Stationers' Hall privilege, but by filling up conspicuous deficiencies and by introducing-in almost too large a proportion-Continental literature and philosophy hardly represented before. The works thus added by purchase form the most valuable constituents of the library, regarded from a utilitarian point of view. They are the "standard books which no library should be without "; they have been got, presumably, as the most necessary, in the judgment of the Committee, to meet the main requirements of such a collection, as ministering to the claims of the teaching staff, and to the needs of the students. But-apart from the facts, that, without any corresponding expansion of resources, the supply is now altogether inadequate to satisfy the larger and more urgent demands of increased literary and scientific production and of new fields of study; that the deficiencies of the collection soon become, in the light of research, fully as obvious as its possessions; and that new subjects can only, in the absence of further aid, be provided for at the expense of the old-it may be said that the elements thus accruing by selection and purchase give to the Library a common, rather than a distinctive or special character. They are necessarily very much the same as are to be found in any similar institution. They are, comparatively speaking, tame, commonplace, and colourless. They lack variety; they are useful rather than interesting; they are nowise peculiar; they have little-at least from the booklover's or bibliographer's point of view-to stimulate curiosity or call forth enthusiasm. Perbaps the collector or amateur is difficult to please. If we give him a Library furnished with all the profuse gifts of the Copyright $\Lambda$ ct, he regrets the absence of choice; if you give hin the results of a choice turning on the useful, he desiderites the presence of the ornamental, the rare, the quaint, and curisus. He wants something out of the common line and range; he longs for what is distinctive, and finds his supreme felicity in what is unique. Now, without endorsing all the whims or follies of the bibliophile or the bibliomaniac, we may yet so far share his satisfaction when, in addition to the more general elements of uscfulness, a great Library possesses features of a more special character or exceptional interest.

III. This pleasure we obtain when we turn to the third great source whence the University Library has derived its most 
characteristic and distinctive possessions - the gifts of individual books, and still more of special collections with which it has been at various times enriched; largely during its earlier daysfar more scantily during its second period, when the wrongly assumed sufficiency of supply under the Copyright Act seems to have injuriously checked the flow of donations-but again in fuller and more varied streams during the last fifty years. In this respect the Library may be pronounced relatively rich. It is, indeed, a very remarkable circumstance that during the last 300 years it has received hardly anything in legacies or money gifts-only, I think, about $£ \mathrm{I}, 500$-while in this country enormous sums have been lavished on bursaries (as though a provision for an individual student were more important than a more ample equipment of resources for the intellectual nourishment of the University as a whole); and, on the other side of the Atlantic, the munificent benefactions of American citizens toward their University Libraries may be in various instances reckoned by millions of dollars. But it has been, at any rate, more fortunate in the receipt of gifts in kind. In these all ranks and conditions of men have had a part, from royal donors like Queen Anne and George III., the Kings of Spain and Naples, the Emperor of Russia, and the King of Siam, down to peers and country gentlemen, successful merchants, enterprising tradesmen, missionaries abroad, principals and professors at home (sometimes commendably presenting their own works), and last, but not least, grateful graduates and students. It is enough to say that each year's gifts are now recorded in the Calendar, and that the number of individual or corporate donors (excluding Universities exchanging Calendars) so recorded for last year was 213. The collections given, if not always large, are considerable in number, variety, and value. To a brief notice of the chief of these I shall devote the remainder of my remarks, premising that the noblest and most precious of all, which might otherwise throw the rest in the shade-the Hunterian Library-does not here come under review. I might take them in the chronological order of their bestowal, which would best show the growth of the Library ; but it may better, perhaps, illustrate the significance of such accessions in enriching as well as augmenting, if we glance in succession at some of the leading departments or special branches.

I. To begin with the Bible, already represented by a MS. of the Vulgate on vellum, the gift of Duncan Bunch almost at the 
outset, the first printed book entered in the catalogue of 1578 is fitly Castalio's Latin Bible, given by the Rector, Andrew Hay. The first Greek Bible came in 1581, from James Boyd, Bishop of Glasgow; the first Hebrew Bible was given in 1586, by Archibald Crawford; the Antwerp Polyglot was bequeathed by Law, Bishop of Glasgow; Walton's Polyglot was given by the founder of the Snell Exhibitions about 1670, and another copy in 1698 by the Earl of Eglinton; Eliot's Indian Bible in I693 by a bookseller in Boston; and the Codex Sinaiticus, upon its issue in 1863 , by the Emperor of Russia. Many translations into foreign languages have been given at different times by Bible Societies, or by the missionaries who have translated them. But all these individual gifts pale before the unique collection of Bibles, bequeathed in 1874 by the late Mr. William Euing, which now lines the walls of the University Court Room. It contains about 3,000 volumes, about 2,000 different editions, and versions in nearly 50 languages. The Complutensian and almost all the Polyglots are there; about 25 editions of the Septuagint; I80 Greek New Testaments; Igo forms of the Bible, or portions, in Latin, including 70 editions of the Vulgate; over 90 forms of the French; and about I,300 copies of the Bible, or parts of it, in English; first editions of the Gaelic, Welsh, Irish, Icelandic, Rumansch, and numerous others almost equally rare. But it is the less necessary to dwell on the contents of this collection as an excellent condensed notice of it was prepared by the Librarian, Mr. Lymburn, for the visit of the Library Association.

2. The several departments of theology-Patristic, exegetical, controversial-were, as might be expected, well represented in the earlier period by such gifts as 48 volumes from the Bishop of Glasgow, in 1581 ; 116 volumes from Howeson, minister of Cambuslang, in 1619 ; and 60 in the same year from Alexander Boyd, gratefully said "to exceed the value of 500 merks ;" I 50 volumes a few years later from Law, Bishop of Glasgow ; 40 volumes - "all in folio "-from William Struthers, minister at Edinburgh, and all that Zachary Boyd "happened to have at his decease." The religious literature of a later date finds special expression in about 700 volumes presented by the late Mrs. Black from her husband's library-in the collection of Glasgow printed books other than Foulis, mainly religious, formed by Mr. Euing, and in the relative portion of his general library, where probably 2,000 volumes bear this 
complexion. To Mr. Euing, e.g., we owe 46 entries under Thomas a Kempis and 33 under Bunyan.

3. A kindred enrichment-still more special in character and value as almost exhausting its range-is the noble collection of books on Palestine formed by the late Dr. A. B. $M$ 'Grigor, and generously presented to the Library by his son. It consists of 655 volumes bearing on the natural, civil, and sacred history of the Holy Land, and especially illustrating the topography and antiquities of Jerusalem, of which Dr. $M$ 'Grigor found time, during a busy life, to make a special study. It is rich in early pilgrimages and Crusading chronicles, as well as in modern books of travel, and numerous illustrated works. Professor G. A. Smith found it specially useful in preparing his recent book on the Historical Geography of Palestine.

4. The Faculties of Medicine and Law have been less fortunate in the measure of their gifts. In the former, the first book seems to have been the Anatomical Plates of Vesalius, presented by Peter Blackburn in $15^{82}$; and in 1590 several volumes in medicine, surgery, and materia medica came, strange as it may seem, from "Mark Jameson, vicar of Kilspendy"; a large paper copy of Harvey's Works came, in 1769, from Dr. William Hunter; and a large number of medical works and dissertations commemorates the interest of the late Dr. Allen Thomson in the Library which at one time he took a leading part in administering. Ioo medical volumes were lately' given by Mr. Evans, a former student. In Law, the chief gift is the not very manageable one of a series of the papers lodged in cases in the Court of Session, which have for 40 years or more been, at the request of a former Professor of Law, set aside by the sanction of the Court for the University Library.

5. It is when we come to the field of the old Arts studies and of science that we encounter most of our prominent benefactions. On the classical side the foundation was at once laid, in 1578 , with 20 volumes given by George Buchanan, and described by Baillie as "a parcel of good Greek books noted with his hand." Isolated works have come at intervals from various donors; but the main accession in this department is due to the General Library of Mr. Euing, which, remarkable for the great variety of interest over which the venerable collector's taste ranged, laid its foundations-alongside that of the Biblical-in a large collection of those early editions of the Classics-now as unduly slighted 
as they were, perhaps, once extravagantly adored-numerous and choice specimens of the Aldine, Stephanic, Elzevir, Baskerville, Foulis, Didot, and Bodoni presses. Of 134 editions of Horace, e.g., in the Library, 64 belong to the Euing and ig to the Hamilton. The latter (of which we shall speak later) is singularly rich in post-classical and modern Latin compositions, both in verse and prose. It contains, to take a single department, Florilegia, 37 ; Poemata, 63 ; Carmina (lyrica), 32; Epigrammata, 40; Epistolæ, 69; Orationes, 53. Sir William Hamilton was fond of collecting works of Buchanan, whose life he had some thoughts of writing. The Alphabetic Catalogue has 67 entries under Buchanan, of which 15 are due to the Euing and no less than $3^{1}$ to the Hamilton.

6. In Philosophy, we learn that Dr. Thomas Reid, in 1797, desired that such books of his as were not in the Library should be presented to it; but, for whatever reason, the outcome was little more than sixty volumes, chiefly of French Belles Lettres. It is to the late Professor Veitch that the University owes one of its noblest gifts, the Library formed by his former teacher and friend, Sir William Hamilton, purchased, on Mr. Veitch's suggestion, by some leading citizens of Glasgow at a cost of $£^{2,000}$, in 1878 , and presented to the University from which Sir William had gone as a Snell exhibitioner to Oxford. It contains about 8,000 volumes, consisting mainly of treatises on Logic and other branches of philosophy, but with many books on the history of Education and of Universities, on Grammar and Rhetoric, and on General History. It brought in 228 treatises on Logic, 57 on Psychology, 26 on Anthropology, and $5 I$ on Metaphysics, and no less than 145 editions of collected or individual works of Aristotle. There is a large representation of the Kantian philosophy, but nothing of Hegel save one or two burlesques. There are about 160 volumes of MS., chiefly dictates of Scottish or Continental Professors of Logic, or of books whose interest lies in their marginal annotation by famous scholars. A special feature illustrative of Hamilton's interest in scholars and scholarships is the number of books of Table Talk or Anecdote, called $A n a$, of which he bad no less than 30 , with 16 others cognate though not so named, 24 of Maxims or Apoph. thegms and 16 of Proverbs; while there are numerous dissertations dealing with quaint and curious themes, of which I am tempted to give one or two specimens as curiosities of the literature of Endition. It is plain that the scholars of the seventeenth 
century, to which most of these academic recreations belong, if they did not examine and depict themselves, kept a sharp eye and caustic tongue for the weaknesses and faults of their learned brethern. The changes are rung on the fortunes, habits, foibles, and failings of "the learned," (eruditi), and they receive (judging from the titles of these disquisitions) much gratuitous advice for the regulation of conduct. One deals with their "diet," another with their "manners," while a third treats of "those that are without manners." Several comment on marriage, its advantages and drawbacks; on bachelor scholars; on the bad wives that may befall them; what sort of a wife the scholar should wed, or the philosopher, or the physician; how to lead a studious life in matrimony. Others treat of their various classes, as scholars who are merchants, or laymen, or living in the country. Others handle their faults, such as their misanthropy, their hatred of women, their disregard for order and neatness, their inability to express their sentiments, their charlatanry, their mania for titles. There are dissertations on literary plagiarism, literary idolatry, and literary Machiavellism, which is explained as "the perverse arts whereby men gain distinction in the republic of letters." And one is entitled "A programme showing the hideous portrait of an clementary old man, i.e., one who has never got beyond the mere rudiments of culture."

But, resuming our review, we find a valuable addition to the Hamilton in part of Mr. Veitch's own library, presented recentiy by Mrs. Veitch, rare and curious works of mediæval or scholastic philosophy, numbering fully 500 volumes, of which about 370 are new to the shelves.

7. On the mathematical and physical side comes first the collection formed by Robert Simson, Professor of Mathematics, 1711-1760, well-known as the "restorer" of Euclid. There are 904 volumes, containing the first and 22 other editions of Euclid; a large representation of other Greek and later geometry; and works on arithmetic, algebra, fluxions, astronomy, and physics. 300 volumes relating chiefly to mathematics and engineering came, in 1777 , from Lieut.-Colonel Paton, chief engineer a: Plymouth; various books on engineering came about twenty years ago from the representatives of Professors Lewis Gordon and Macquorn Rankine; sets of Transactions of the Civil and Mechanical Engineers and the Naval Architects have been presented of late years; and Lord Kelvin has twice transferred to the Library a large body of the Transactions, memoirs, and 
scientific papers which have been presented to him by their authors. This great accession comprises about 800 volumes of scientific periodicals and transactions, and nearly 5,000 papers and pamphlets relating largely to electricity, but embracing much in almost every department of Natural philosophy. The late Alexander Macdonald, M.P., bequeathed about I 50 volumes on mining; and the Library has just received-what is not less memorable than any past gift-a special subsidy for the future in a capital grant of $€ 500$ and an anuual grant of $£$ 100 by the Bellahouston Trustees for the purchase of scientific and technical periodicals.

8. In Botany the resources of the student were greatly increased by the botanical Library of Dr. Walker-Anott, which, along with his extensive herbarium and carefully arranged cabinets of Diatoms were purchased, in 1868 , partly by private subscription (in response to an appeal by Professor Cowan and myself), partly by a special grant from the University funds. Apart from 70 volumes accompanying the herbarium, it contains 970 volumes of the most important works of systematic and descriptive botany, local Floras, many of them valuable and rare (such as Sibthorp's Flora Græca), and Icones Plantarum. Many years ago a friend gave me the means of procuring a set of plates of the Botanical Magasins and Botanical Register, specially arranged by the natural orders; and more recently another friend has enabled me to complete Dr. Walker-Arnott's copy of Curtis' Botanical Magasine, which had not been continued after his death.

In Zoology we have no gift similar to the Walker-Arnott. But we get important books presented at intervals, of which, e.g., it is enough to mention the 50 volumes of the Challenger Expedition from our own Government, and the Fauna and Flora of the Gulf of Naples, which has just been presented by one of the Library's most enlightened benefactors at a cost of nearly $£ 70$.

9. In Music, while Mr. Euing naturally associated his unrivalled collection with the chair which he founded and attached to Anderson's College, the late Mr. Thomas L. Stillie, well known as a musical connoisseur and critic, bequeathed, in 1884 , his musical library, numbering 760 volumes, containing the works of the chief composers, many of them in full score, and an extensive series of modern operatic compositions, Continental and English. 
ro. In Archæology and Art we have such gifts as the "Antichita di Ercolano," in 1764, from the King of Naples; the Ionian Antiquities from the Dukes of Buccleuch in 1770"; the engravings of the two Piranesi, from the Marquis of Graham, in $\mathrm{I} 788$; an unique volume containing original water-colour drawings of frescoes from the ruins of Rome in the year 1674 , presented by Dr. Connel of "The Lillies," Bucks, through Professor Veitch; and many works on antiquities, architecture, and painting in the Euing Library, including $4 \mathrm{I}$ books on pottery and porcelain, which were among his latest acquisitions.

I I. In Scottish antiquities, local and family history, while the University Library subscribed to several of the leading Clubs, such as the Bannatyne, Maitland, and Spalding, it owed several of their earlier volumes to the gift of the contributors. Its first collective gift in this department was that of Mr. John Smith, bookseller, and founder of the Maitland Club, who, about I847, bequeated about 350 volumes, containing, with other club books, a set of the Percy Society and the Abbotsford Club, and a very remarkable collection of Glasgow pamphletsMr. Smith baving been careful to preserve and bind, apparently, whatever reached him of the passing literature of the day and the street, reports of local societies and public meetings, circulars, political manifestoes, election squibs and placards, tracts, ballads, and chap books. A few years ago, the surviving members of the Maitland Club, on winding it up, banded over to the Library, with several club books, 28 volumes, containing the correspondence which Mr. Smith, as secretary, had conducted as to their publications, one volume preserving only letters of acceptance or excuse for the annual dinners of the club. In 1879, Mr. Charles Heath Wilson presented II volumes of his correspondence as to the stained windows of Glasgow Cathedral. Another collection of pamphlets, more general in character, but having much illustrative of Glasgow, formed by the late Dr. M'Grigor and given by his son along with the Palestine library, extends to 83 volumes. Many family histories have come from their authors or from the heads of the families concerned-most notable of all, the series so closely linked with the name of Sir William Fraser, to whom the Library owes much for suggesting it as a fitting repository of his monumental labours. Of these we have an almost complete set, 41 volumes.

12. Two or three years ago, the late Dr. M'Callum, in con- 
nection with his provision of a Celtic Lectureship, bequeathed his library of more than 3,000 volumes, containing a good nucleus of Celtic books and many standard works of general literature, along with an annual sum of $£$ io for its increase on the Celtic side.

13. In English and Miscellaneous Literature, Mrs. Eck, some years ago, contributed 800 volumes from the library of her late husband, and there have been various minor gifts. But far the most valuable accession from the general collector's or booklover's point of view, came here, too, from Mr. Euing, of whose General Library I must now convey some slight idea in conclusion, by touching on one or two of its leading features other than have been noticed already. It contains 10,348 volumes or thereby. Of ballads and songs there are 63 English and 28 Scottish collections; and there is a set of Elizabethan broadsides which cost $£ 350$. Of Shakespeare he had the first two folios, an almost complete set of the Ashbee lithographed facsimiles of the separate Plays; Halliwell-Phillips' edition with India proofs ; and most of Halliwell's and Collier's rare reprints. There are 17 entries under Allan Ramsay; of books edited or written by Ritson, 28 ; by Sir Egerton Brydges, 48 ; by Thomas Wright, 37. In bibliography, most of Dibdin's works are represented in large paper copies; and there are 23 entries under Peignot, who had no place in the Catalogue before. Of " fifteeners," the Library had previously about 50 ; it received I 50 from Mr. Euing. Of the Bodoni printing press at Parma there are 80 specimens; and of the Foulis press at Glasgow no fewer than 390. There are nine editions of Reynard the Fox, seven of the Encomium Moriæ; books of emblems, 20; of epitaphs 62 (as well as 22 on tombs and monumental brasses); of jest books, 20; on angling, 33; a unique copy of Bruce and Wallace (in the Glasgow reprint) thrown off for Mr. Euing specially on vellum; and of MSS., a beautiful Latin Bible and several illuminated Horae.

I have thus mentioned about 34,000 volumes as having come by gifts, and it is safe to affirm that nearly 40,000 have been so added, or about one-fourth of the whole. An American tourist, who is apt to judge merely by numbers, might deem this relatively small, as compared with the mammoth increments of Transatlantic libraries fed by liberal millionaires; but, looking to the special character, variety, and quality of those gifts, we have little to be ashamed of, and much to be thankful for. Private 
collections have become stepping-stones to public benefactions, and if a book-lover has derived special enjoyment from the gathering and possession of his stores, he can hardly have a greater satisfaction than by disseminating congenial tastes and extending the opportunities for gratifying them, where the pleasure is not diminished by being shared. One thing only I add, that while such donations are always welcomed, whether by the University Library, by the Mitchell, or by Stirling's and Baillie's, the donors may greatly enhance the value of their gifts by permitting the disposal of duplicates, subject only to the condition that the proceeds be applied to the purchase of kindred works, which may be incorporated with and enrich the store already given. 